\title{
Synthesis of silicon carbide from rice husk
}

\section{(Síntese de carbeto de silício a partir de casca de arroz)}

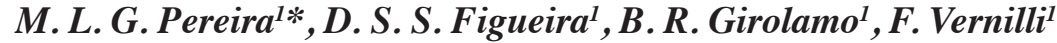 \\ ${ }^{1}$ University of São Paulo, Department of Materials Engineering, 12600-970, Lorena, SP, Brazil
}

\begin{abstract}
This is a study about the synthesis of $\mathrm{SiC}$ from rice husk. The $\mathrm{SiC}$ production was carried out in two stages, the first one being the rice husk carbonization under vacuum, at the temperature range from 270 to $650{ }^{\circ} \mathrm{C}$, and the second stage was the pyrolysis of the carbonized rice husk, at the temperature range from 1300 to $1800{ }^{\circ} \mathrm{C}$ and $120 \mathrm{~min}$ isotherms. The rice husk was characterized by X-ray fluorescence, and the reaction products were characterized by X-ray diffraction and scanning electron microscopy. The temperature influence on pyrolysis was demonstrated. $\mathrm{SiC}$ formation occurred in samples treated over $1600{ }^{\circ} \mathrm{C}$, while at lower temperatures, it was possible to observe the secondary formation of cristobalite, tridymite, and quartz. In this study, it was possible to calculate the yield of $\mathrm{SiC}$ production as a function of the pyrolysis temperature of the carbonized rice husk.
\end{abstract}

Keywords: silicon carbide, $\mathrm{SiC}$, rice husk, pyrolysis.

Resumo

Neste estudo, a casca de arroz foi utilizada para a síntese de SiC. A produção do SiC foi realizada em duas etapas, sendo a primeira etapa a carbonização da casca de arroz sob vácuo, variando-se a temperatura de 270 a $650{ }^{\circ} \mathrm{C}$, e a segunda etapa a pirólise da casca carbonizada, nas temperaturas de 1300 a $1800{ }^{\circ} \mathrm{C}$ e isotermas de $120 \mathrm{~min}$. A casca de arroz foi caracterizada por fluorescência de raios $X$ e os produtos da reação foram caracterizados por difratometria de raios X e microscopia eletrônica de varredura. A influência da temperatura de pirólise foi demonstrada. A formação do SiC ocorreu nas amostras tratadas a partir de $1600{ }^{\circ} \mathrm{C}$; em temperaturas inferiores observou-se a formação secundária de cristobalita, tridimita e quartzo. Neste estudo, foi possível calcular o rendimento da produção do SiC em função da temperatura de pirólise da casca de arroz carbonizada.

Palavras-chave: carbeto de silício, SiC, casca de arroz, pirólise.

\section{INTRODUCTION}

Silicon carbide ( $\mathrm{SiC})$ is one of the most important ceramic materials which are produced on a large scale. It has many industrial applications due to its high hardness, thermal and electrical conductivity, excellent corrosion, and thermal shock resistance $[1,2]$. Its main applications are as structural materials, abrasives, refractories, electronic components, and nuclear reactors. The main method of $\mathrm{SiC}$ synthesis is a carbothermal reduction known as the Acheson process, which is an energy-intensive process making $\mathrm{SiC}$ a high-cost product [3]. Over the past 4 decades, many researchers have studied the use of rice husk as an alternative raw material for silicon carbide [3-13]; Lee and Cutler were the first two scientists to synthesize $\mathrm{SiC}$ from rice husk [14]. The benefit of using rice husk as a raw material is its low cost since in most cases the husk is considered a waste [15]; also $\mathrm{SiC}$ formation occurs at lower temperatures (1200 to $1500{ }^{\circ} \mathrm{C}$ ) when compared to the reactions between solid quartz and graphite (1200 to $2000{ }^{\circ} \mathrm{C}$ ); according to Eqs. A to $\mathrm{C}$ [16-18], this is due to the high surface area of the rice

*luiza.pereira@usp.br

Dhttps://orcid.org/0000-0002-3303-3998 husk and the presence of an ionic mixture between silica and carbon in its composition.

$$
\begin{aligned}
& \mathrm{SiO}_{2(\mathrm{~s})}+3 \mathrm{C}_{(\mathrm{s})} \rightarrow \mathrm{SiC}_{(\mathrm{s})}+2 \mathrm{CO}_{(\mathrm{g})} \\
& \mathrm{SiO}_{2(\mathrm{~s})}+2 \mathrm{C}_{(\mathrm{s})} \rightarrow \mathrm{Si}_{(\mathrm{s})}+2 \mathrm{CO}_{(\mathrm{g})} \\
& \mathrm{SiO}_{2(\mathrm{~s})}+\mathrm{C}_{(\mathrm{s})} \rightarrow \mathrm{SiO}_{(\mathrm{g})}+\mathrm{CO}_{(\mathrm{g})}
\end{aligned}
$$

Rice is one of the most consumed food in the world; according to the United States Department of Agriculture (USDA), the 2017/2018 world harvest was estimated at about 481.2 million tons [19]. China is the world's largest rice producer, and its harvest for 2017/2018 is estimated at 144 million tons. For Brazil, the estimate is 11.87 million tons [20]. As the husk represents about $22 \%$ of the grain weight, Brazil generated nearly 2.6 million tons of waste in 2018. Rice husk contains cellulose as its main constituent, an organic material that generates carbon when thermally decomposed in a reducing atmosphere, also has a high silica content ( $13 \%$ to $29 \%$ by weight). The ash is mainly composed of silica (87\% to $97 \%$ by weight), small amounts of alkali, and traces of other elements [21]. SiC formation usually occurs in two stages. First, the rice husk is pyrolyzed in a reducing atmosphere at temperatures between 700 and 
$900{ }^{\circ} \mathrm{C}$; the product of this decomposition is then treated at temperatures around $1500{ }^{\circ} \mathrm{C}$ in an inert or reducing atmosphere [22]. Krishnarao and co-authors conducted several studies on the silicon carbide production from rice husk pyrolysis, in vacuum [22-24] and argon atmosphere [6, 25]. In one study, they found that the maximum formation of filament-shaped silicon carbide occurred in samples treated at $1320^{\circ} \mathrm{C}$, and, as the pyrolysis temperature increased, there was a tendency for filament recrystallization; at $1510^{\circ} \mathrm{C}$, the product became mainly particulate [5]. They also studied the inclusion of additives such as silicon nitride $\left(\mathrm{Si}_{3} \mathrm{~N}_{4}\right)$ [23], cobalt chloride $\left(\mathrm{CoCl}_{2}\right)$ [26], and cobalt [27] in the silicon carbide production. Recently, Li et al. [11] presented a synthesis route to obtain nanostructured $\mathrm{SiC}$ powder by microwave heating using rice husk as raw material. The carbothermal reduction reaction was performed at $2.45 \mathrm{GHz}$ in an argon atmosphere. Gorzkowski et al. [28] also demonstrated that large amounts of $\beta-\mathrm{SiC}$ nanostructures can be obtained by pyrolysis of rice husk in a single step under controlled temperature $\left(1375^{\circ} \mathrm{C}\right)$ and atmosphere (argon) conditions.

Rice husk is still an environmental problem today, as not all waste generated is disposed of properly, especially in countries that produce large amounts of rice, such as China, India, and Brazil $[4,16]$. On the other hand, the silicon carbide production industry requires a source of high-purity silica and carbon. The most critical $\mathrm{SiC}$ manufacturing issues in recent years have been the cost and availability of coke and silica, the cost of electricity, and environmental considerations [29]. The viability of rice husk would minimize the environmental impact generated by reducing husk disposal and quartzextraction. The main objective of this study was to produce pure silicon carbide, without residual silica and graphite, and for this, the process conditions such as $\mathrm{SiO}_{2} / \mathrm{C}$ molar ratio and pyrolysis temperature were adjusted. The syntheses were performed with excess carbon to obtain a $\mathrm{CO}$-rich atmosphere to produce a $\mathrm{SiC}$ without silica. In most cases, a chemical process with hydrofluoric acid is performed on the $\mathrm{SiC}$ to remove residual silica; in this study, this step was not performed. In this study, it was also possible to calculate the yield of $\mathrm{SiC}$ production from the rice husk.

\section{EXPERIMENTAL PROCEDURE}

Carbonization of rice husk (CRH): the rice husk (RH) used in this study was collected at a rice mill in Guaratinguetá, Brazil. The rice husk was sieved to remove possible residues, and its chemical composition was analyzed by X-ray fluorescence spectroscopy (PANalytical, Axios Max). Thermogravimetric analysis was performed on a simultaneous thermal analyzer (Netzsch, STA 449F3) with a heating rate of $10{ }^{\circ} \mathrm{C} / \mathrm{min}$ from 25 to $1200{ }^{\circ} \mathrm{C}$ under nitrogen flow. $\mathrm{SiC}$ synthesis from rice husk was performed in two steps. First, the rice husk was carbonized under vacuum at different temperatures. In this first step, it was possible to adjust a $\mathrm{SiO}_{2} / \mathrm{C}$ molar ratio as a function of temperature. In this study, a carbonized rice husk containing an excess of carbon was produced, and pyrolysis was used in the second step. The carbonization of RH cellulose in carbon was performed in a stainless-steel reactor for $45 \mathrm{~min}$ under vacuum $(680 \mathrm{mmHg})$ at 7 different temperatures, ranging from 270 to $650{ }^{\circ} \mathrm{C}(\mathrm{CRH})$. The resulting carbon content in these samples was determined by heat treatment at $700{ }^{\circ} \mathrm{C}$ for $120 \mathrm{~min}$ in an oxidizing atmosphere.

Synthesis of silicon carbide by carbothermal reduction: for the $\mathrm{SiC}$ synthesis, only the carbonized husk was used, which was placed in a small graphite crucible with a lid. This set was put inside a bigger crucible and covered with graphite powder and heated in an oven (Thermal Technology, Astro 1000-4650-FP20). The pyrolysis was performed in a closed graphite crucible containing the sample in order to maintain the atmosphere rich in $\mathrm{CO}$. Heat treatments were performed at 6 different temperatures $\left(1300,1400,1500,1600,1700\right.$, and $\left.1800{ }^{\circ} \mathrm{C}\right)$ with a heating rate of $20^{\circ} \mathrm{C} / \mathrm{min}$ and $120 \mathrm{~min}$ isotherms. Heating was performed under vacuum; upon reaching the maximum temperature, the vacuum was broken with argon, maintained during treatment, and then cooled until reaching $70{ }^{\circ} \mathrm{C}$. After synthesis, the obtained products were treated at $700{ }^{\circ} \mathrm{C}$ for $24 \mathrm{~h}$ to remove residual carbon. Fig. 1 shows the flow chart of the $\mathrm{SiC}$ production from rice husk.

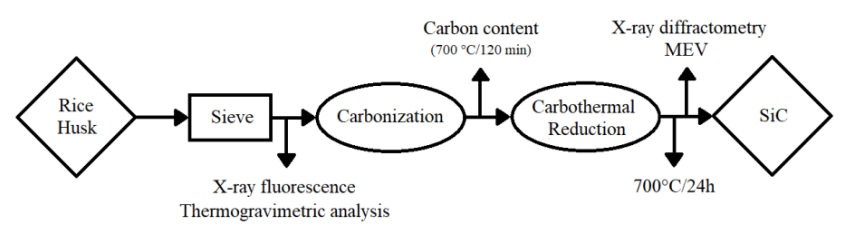

Figure 1: Flowchart of the $\mathrm{SiC}$ production from rice husk.

[Figura 1: Fluxograma da produção de SiC a partir da casca de arroz.]

Analysis of the crystalline phases by X-ray diffractometry of the powder after synthesis was performed using $\mathrm{CuK} \alpha$ radiation $(\lambda=1.5406 \AA)$ with nickel monochromator and PIXcel 3D detector, with a step size of $0.01^{\circ}$ and $2 \theta$ ranging from $10^{\circ}$ to $90^{\circ}$ in a diffractometer (PANalytical, Empyrean) with a software (PANalytical, HighScore Plus) for the qualitative and quantitative determination of the formed phases. The phases quantification was performed by the Rietveld method. The microstructure was investigated with a scanning electron microscope (SEM) equipped with a dispersive energy spectrometer (Hitachi, TM 3000).

\section{RESULTS AND DISCUSSION}

Characterization of the rice husk $(R H)$ : Table I shows the result of a chemical analysis of rice husk. This husk had about $10 \%$ of $\mathrm{SiO}_{2}$ in its composition and approximately $1.7 \%$ of other elements, which were considered impurities. 
The loss on ignition was $88.30 \%$; therefore, the ash content was $11.70 \%$. The silica content was in agreement with the literature. According to [9], the silica content in RH ranges between $8 \%$ (fresh RH) and 18\% (stored RH).

Table I - Chemical composition of rice husk ash (wt\%). [Tabela I - Composição química da cinza de casca de arroz. (\% em massa).]

\begin{tabular}{ccc}
\hline Compound & With LOI & Without LOI \\
\hline $\mathrm{SiO}_{2}$ & 10.56 & 90.3 \\
$\mathrm{Na}_{2} \mathrm{O}$ & 0.27 & 2.3 \\
$\mathrm{~K}_{2} \mathrm{O}$ & 0.25 & 2.1 \\
$\mathrm{SO}_{3}$ & 0.18 & 1.5 \\
$\mathrm{CaO}$ & 0.11 & 0.9 \\
$\mathrm{P}_{2} \mathrm{O}_{5}$ & 0.08 & 0.7 \\
$\mathrm{MgO}$ & 0.04 & 0.3 \\
$\mathrm{MnO}$ & 0.04 & 0.3 \\
$\mathrm{Al}_{2} \mathrm{O}_{3}$ & 0.01 & 0.1 \\
$\mathrm{Fe}_{2} \mathrm{O}_{3}$ & 0.01 & 0.1 \\
$\mathrm{Cl}$ & 0.15 & 1.3 \\
$\mathrm{Total}$ & 11.70 & 100.0 \\
\hline
\end{tabular}

LOI - loss on ignition.

Fig. 2 shows the thermogravimetric curves of the rice husk in natura, where it may be observed that rice husk mass loss can be divided into three temperature ranges. The first, with a $10 \%$ loss, occurred up to $200{ }^{\circ} \mathrm{C}$ and corresponded to the moisture incorporated in the rice husk. The second mass loss of about $54 \%$ occurred in the range between 200 and $360{ }^{\circ} \mathrm{C}$ and was related to the decomposition of the hemicellulose and most of the cellulose. Lignin decomposition occurred between 360 and $525^{\circ} \mathrm{C}$, while the total thermal decomposition of the rice husk occurred below $700{ }^{\circ} \mathrm{C}$, corroborating the results in [30].

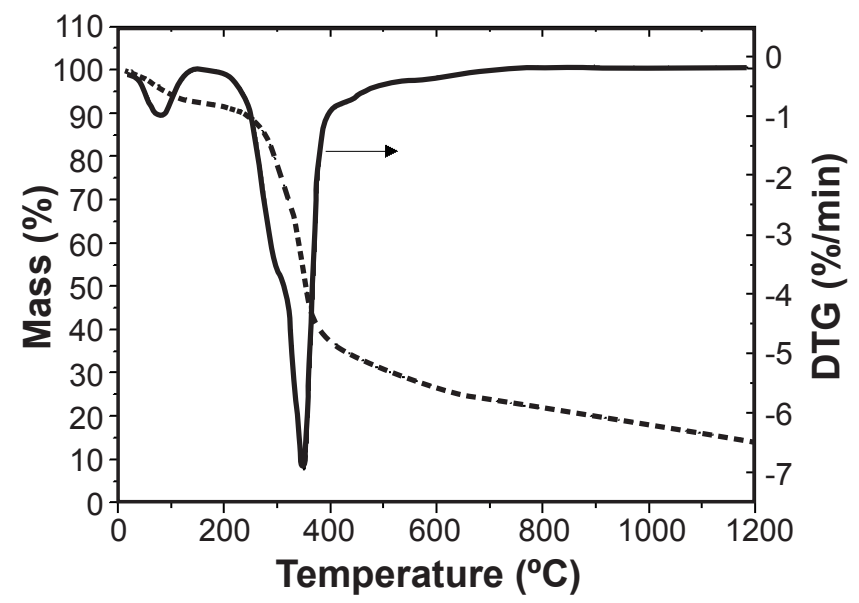

Figure 2: Thermogravimetric curves of rice husk.

[Figura 2: Curvas termogravimétricas da casca de arroz (RH).]

Characterization of carbonized rice husk (CRH): Fig. 3 shows the relationship between carbon and silica contents of the carbonized rice husk (CRH) samples, determined by oxidation at $700{ }^{\circ} \mathrm{C}$ for $120 \mathrm{~min}$. The silica content was considered as $90.3 \%$ of the remaining mass after oxidation, according to the results in Table I. It may be observed that as the carbonization temperature increased, there was an increase in mass loss and, consequently, an increase in the silica concentration of the sample. In this study, a rice husk carbonized at $400{ }^{\circ} \mathrm{C}$ containing approximately $61 \%$ carbon and $35.4 \%$ silica was used for silicon carbide synthesis, therefore, with $\mathrm{SiO}_{2} / \mathrm{C}$ molar ratio of 0.12 , resulting in approximately 3 times the stoichiometric amount of carbon required to form $\mathrm{SiC}$ according to the Eq. A. Krishnarao and co-authors used a black rice husk ash containing $53 \mathrm{wt} \%$ of carbon and $47 \mathrm{wt} \%$ of $\mathrm{SiO}_{2}[5]$, and a raw rice husk with $85 \mathrm{wt} \%$ of organic material and $15 \mathrm{wt} \%$ of $\mathrm{SiO}_{2}[6,31]$. Moustafa et al. [32] used a cooked rice husk containing about $40 \%$ of carbon.

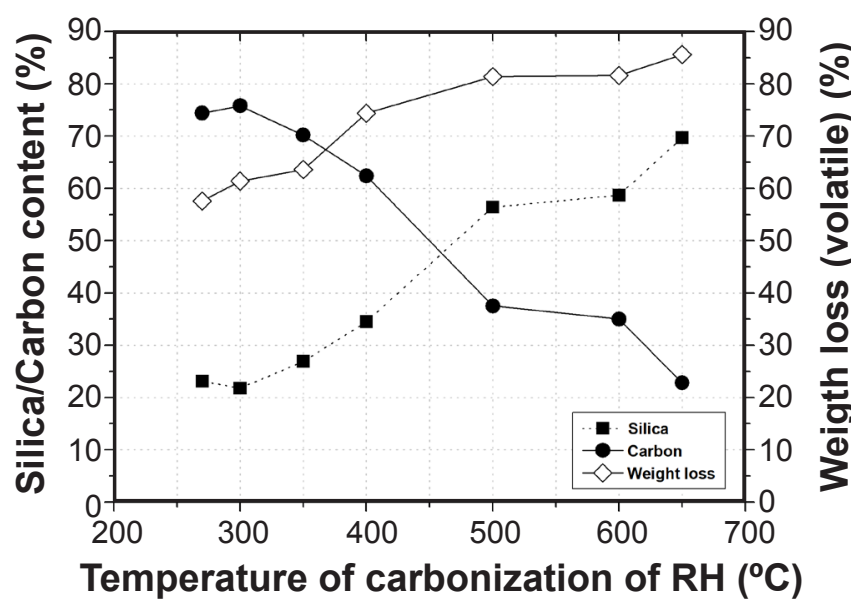

Figure 3: Carbon and silica content as a function of the carbonization temperature of $\mathrm{RH}$.

[Figura 3: Teor de carbono e sílica em função da temperatura de carbonização da RH.]

Synthesis of silicon carbide by carbothermic reduction: Fig. 4 shows the percentages of residual masses obtained after synthesis and heat treatment for carbon decomposition, therefore, the yield is the sum of $\mathrm{SiC}$ and unreacted $\mathrm{SiO}_{2}$. It was observed that about $29.9 \%$ to $43.5 \%$ of the initial mass was converted into a final product, a result well below the theoretical conversion values (Fig. 4). No data were found on the yield of $\mathrm{SiC}$ production from rice husk. The theoretical conversion was estimated, considering that the carbonized rice husk used in the pyrolysis contained $61 \% \mathrm{C}$ and $35.4 \%$ $\mathrm{SiO}_{2}$. For pyrolysis, $1.4 \mathrm{~g}$ of carbonized rice husk was used; therefore, the sample contained $0.854 \mathrm{~g} \mathrm{C}$ and $0.4956 \mathrm{~g} \mathrm{SiO}_{2}$. According to Eq. D, reacting $0.4956 \mathrm{~g}$ of $\mathrm{SiO}_{2}, 0.297 \mathrm{~g}$ of $3 \mathrm{C}$, and $0.557 \mathrm{~g}$ of excess $\mathrm{C}$ resulted in $0.33 \mathrm{~g}$ of $\mathrm{SiC}, 0.46 \mathrm{~g}$ of $\mathrm{CO}$, and $0.557 \mathrm{~g}$ of unreacted $\mathrm{C}$; therefore, the mass of solid products was $0.887 \mathrm{~g}(65.7 \%)$.

$$
\mathrm{SiO}_{2(\mathrm{~s})}+3 \mathrm{C}_{(\mathrm{s})}+\mathrm{C}_{(\mathrm{s}) \text { excess }} \rightarrow \mathrm{SiC}_{(\mathrm{s})}+2 \mathrm{CO}_{(\mathrm{g})}+\mathrm{C}_{(\mathrm{s})}
$$

Fig. 5 shows the X-ray diffractograms of the phase transformation evolution of the carbonized rice husk at $400{ }^{\circ} \mathrm{C}$, after pyrolysis at $1300,1400,1500,1600$, 


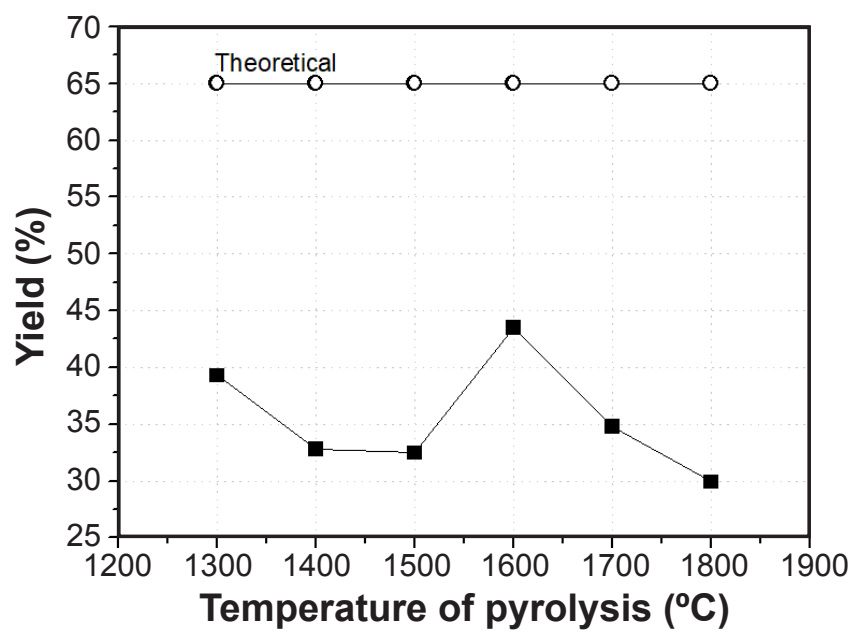

Figure 4: Yields from pyrolysis reaction.

[Figura 4: Rendimento da reação de pirólise.]

1700 , and $1800{ }^{\circ} \mathrm{C}$ with the excess carbon being removed by calcination. In pyrolysis up to $1500{ }^{\circ} \mathrm{C}, \mathrm{SiC}$ formation was not evidenced, only the polymorphic phases of $\mathrm{SiO}_{2}$ were detected in the forms of cristobalite (ICSD 01-076-0935), tridymite (ICSD 01-075-0638), and quartz (ICSD 01-086-1562). $\mathrm{SiC}$ formation was observed from $1600{ }^{\circ} \mathrm{C}$, but still with the presence of $\mathrm{SiO}_{2}$. Pure $\mathrm{SiC}$ formation occurred only from $1700{ }^{\circ} \mathrm{C}$. The carbide formed was mostly in the $\beta$-SiC form (ICSD 01-075-0254); however, traces of $\alpha$-SiC (ICSD 01-089-2213) were also observed. The final yield (Fig. 5) at $1700^{\circ} \mathrm{C}$ was higher $\left(34.8 \%\right.$ ) than at $1800{ }^{\circ} \mathrm{C}$ (29.9\%), due to possible decomposition of $\mathrm{SiC}$ at $1800^{\circ} \mathrm{C}$.

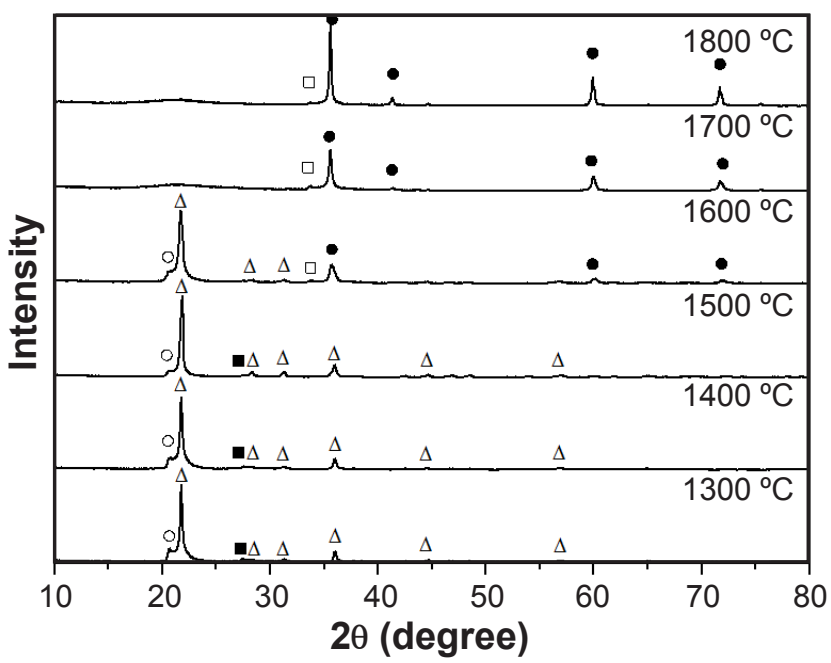

Figure 5: X-ray diffractograms of carbonized rice husk pyrolyzed at different temperatures for 2 h. $\Delta$ cristobalite; $O$ tridymite; quartz; $\bullet \beta-\mathrm{SiC} ; \square \alpha-\mathrm{SiC}$.

[Figura 5: Difratogramas de raios $X$ da casca de arroz carbonizada pirolisada em diferentes temperaturas por $2 \mathrm{~h}$.

Fig. 6 shows the concentration of $\mathrm{SiC}$ and $\mathrm{SiO}_{2}$ in the final product as a function of pyrolysis temperature. As pyrolysis temperature increased, there was a higher $\mathrm{SiC}$ production and lower $\mathrm{SiO}_{2}$ residue, mostly in the form of cristobalite. The same behavior was observed in
$[5,6,31] . \mathrm{SiC}$ began to form at $1600{ }^{\circ} \mathrm{C}$, and between 1700 and $1800{ }^{\circ} \mathrm{C}$, only $\mathrm{SiC}$ was identified. Krishnarao and Godkhindi [5] studied a $\mathrm{SiC}$ production at lower temperatures, ranging from 1100 to $1510{ }^{\circ} \mathrm{C}$; the maximum $\mathrm{SiC}$ concentration in the final product, about $58 \%$, was obtained at $1510{ }^{\circ} \mathrm{C}$. At $1500{ }^{\circ} \mathrm{C}$, no $\mathrm{SiC}$ production was observed in the present study. In the production of $\mathrm{SiC}$ from a raw rice husk [31], it was observed that the production of graphitic carbon continuously increased up to $1600{ }^{\circ} \mathrm{C}$. Graphite formation was not observed in the present study.

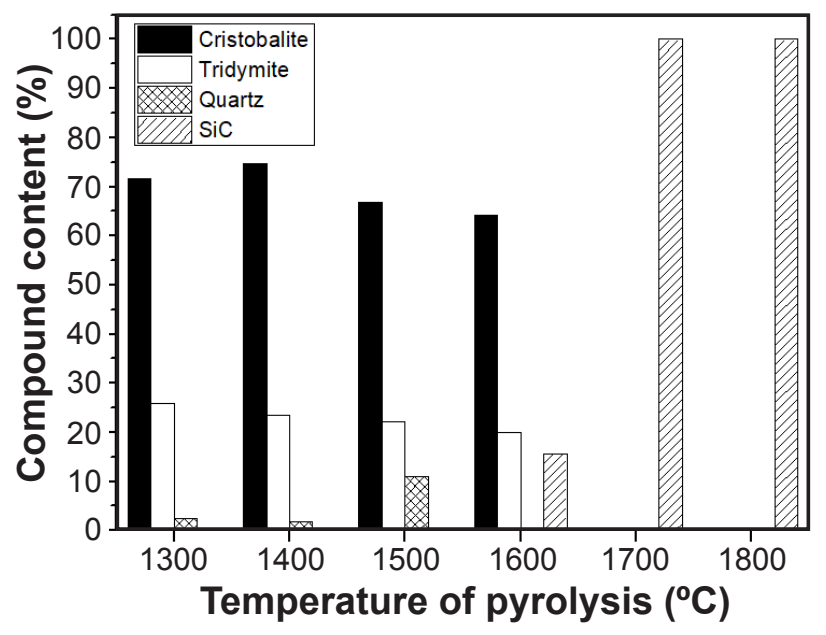

Figure 6: Comparison of $\mathrm{SiC}$ and $\mathrm{SiO}_{2}$ production as a function of pyrolysis temperature.

[Figura 6: Comparativo da produção de $\mathrm{SiC}$ e $\mathrm{SiO}_{2}$ em função da temperatura de pirólise.]

Fig. 7 shows SEM images of the pyrolyzed rice husk at $1500{ }^{\circ} \mathrm{C}$ (Figs. 7a and 7b), $1700{ }^{\circ} \mathrm{C}$ (Figs. 7c and $7 \mathrm{~d}$ ), and $1800{ }^{\circ} \mathrm{C}$ (Figs. 7e and 7f). At 1300, 1400, and $1500{ }^{\circ} \mathrm{C}$, the presence of $\mathrm{SiC}$ was not observed, but only silica, mostly in the form of cristobalite. It was clearly observed that the $\mathrm{SiC}$ formed had two distinct morphologies: whiskers and particles. Between 1600 and $1700{ }^{\circ} \mathrm{C}, \mathrm{SiC}$ formation was observed mostly in the form of whiskers. At $1800{ }^{\circ} \mathrm{C}$, there was a decrease in whisker formation, and particulate $\mathrm{SiC}$ appeared. According to [5], when the pyrolysis temperature is increased, the formed filaments tend to recrystallize, and the product becomes predominant in particulate form. The $\mathrm{SiC}$ whisker formation seems to achieve a maximum in samples treated at $1700{ }^{\circ} \mathrm{C}$. Krishnarao et al. [22] showed that there are competitive processes during the pyrolysis of rice husk: crystallization of amorphous silica, crystallization of amorphous carbon, and the reduction of $\mathrm{SiO}_{2}$ to form $\mathrm{SiC}$ particles and whiskers. In the present study, the crystallization of the amorphous silica was observed at temperatures from 1300 to $1500{ }^{\circ} \mathrm{C}$. Above $1500{ }^{\circ} \mathrm{C}$, the reduction of $\mathrm{SiO}_{2}$ to form $\mathrm{SiC}$ occurred. At $1700{ }^{\circ} \mathrm{C}$, the rate of $\mathrm{SiO}$ liberation and the rate of $\mathrm{SiC}$ formation were probably low, favoring the formation of $\mathrm{SiC}$ whiskers. As the temperature increased, the rates of $\mathrm{SiO}$ release and $\mathrm{SiC}$ formation were probably high and favored the formation of $\mathrm{SiC}$ particles. 

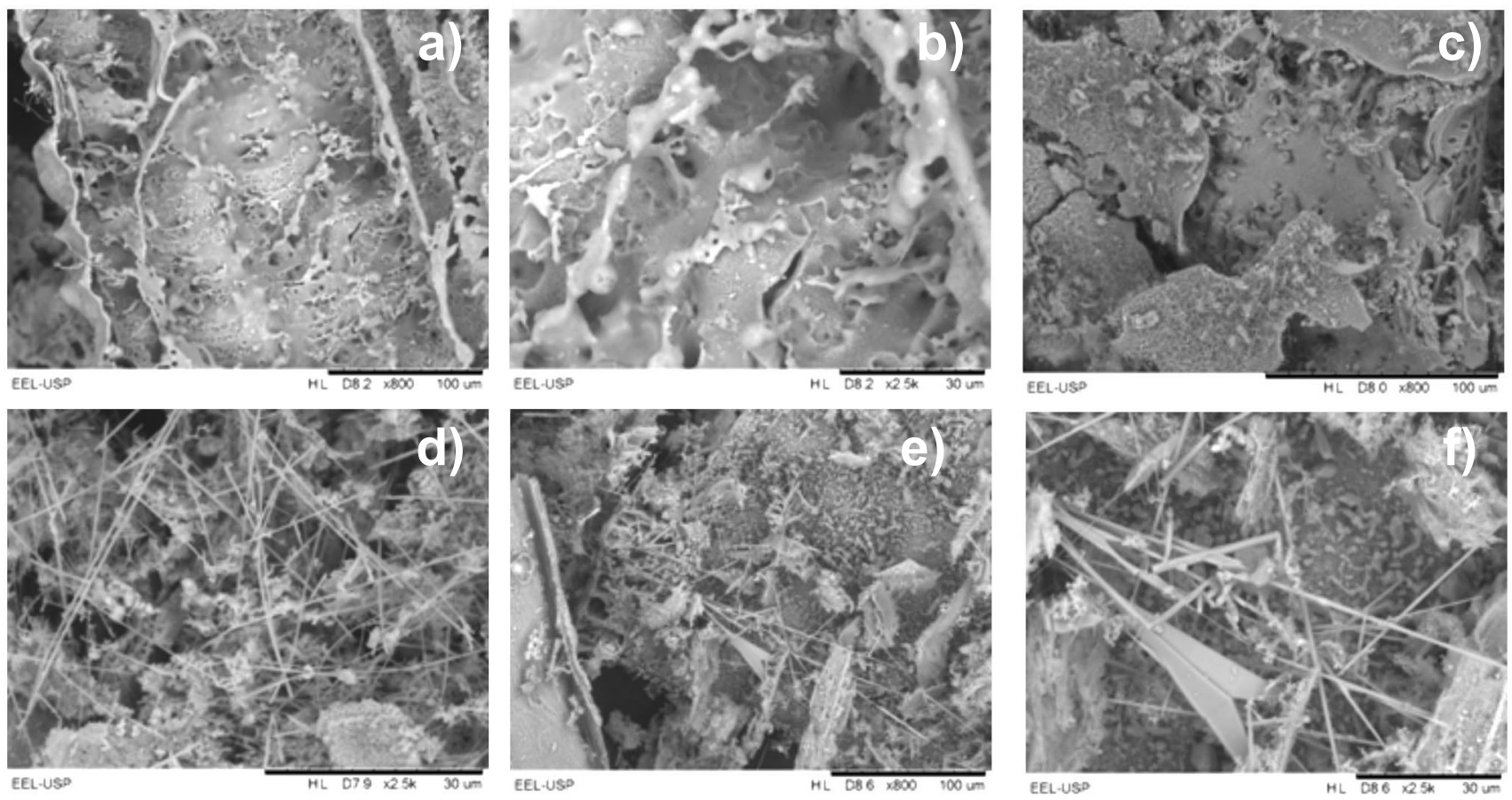

Figure 7: SEM micrographs of the pyrolyzed rice husk at $1500^{\circ} \mathrm{C}(\mathrm{a}, \mathrm{b}), 1700{ }^{\circ} \mathrm{C}(\mathrm{c}, \mathrm{d})$, and $1800{ }^{\circ} \mathrm{C}(\mathrm{e}, \mathrm{f})$.

[Figura 7: Micrografias de MEV da casca de arroz pirolisada a $1500{ }^{\circ} \mathrm{C}(a, b), 1700{ }^{\circ} \mathrm{C}(c, d)$ e $1800{ }^{\circ} \mathrm{C}(e, f)$.]

\section{CONCLUSIONS}

SiC synthesis from rice husk was performed in a twostep process: carbonization and pyrolysis. It was concluded that pyrolysis temperature influenced $\mathrm{SiC}$ formation. $\mathrm{SiC}$ in whisker form was formed at 1600 and $1700{ }^{\circ} \mathrm{C}$. At $1800^{\circ} \mathrm{C}$, there was a decrease in the whisker and particle formation of $\mathrm{SiC}$; however, at 1700 and $1800{ }^{\circ} \mathrm{C}$, only the $\mathrm{SiC}$ phase was identified by $\mathrm{X}$-ray diffraction analysis; therefore, it was possible to obtain the $\mathrm{SiC}$ from rice husk. The $\mathrm{SiC}$ content in the final product from rice husk ranged from $15.7 \%$ to $100 \%$, and the yield was $34.8 \%$ at $1700{ }^{\circ} \mathrm{C}$ and $29.9 \%$ at $1800{ }^{\circ} \mathrm{C}$. Therefore, the use of rice husk in $\mathrm{SiC}$ production can bring several benefits beyond the environmental one; there could also be a reduction in the cost of the raw material since the rice husk is in most cases considered as waste and due to the intimate contact between silica and carbon, the rice husk has a high surface area which can lead to the formation of $\mathrm{SiC}$ at lower temperatures.

\section{REFERENCES}

[1] K. Ahmad, M. Ali, A. Ibrahim, W.M. Baig, J. Mater. Sci. Eng. 3, 3 (2014) 1.

[2] S. Niyomwas, J. Met. Mater. Miner. 19, 2 (2009) 21.

[3] G.T. Adylov, Sh.A. Faiziev, M.S. Paizullakhanov, S. Mukhsimov, É. Nodirmatov, Tech. Phys. Lett. 29, 3 (2003) 221.

[4] N. Soltani, A. Bahrami, M.I. Pech-Canul, L.A. González, Chem. Eng. J. 264 (2015) 899.

[5] R.V. Krishnarao, M.M. Godkhindi, Ceram. Int. 18 (1992) 35 .
[6] R.V. Krishnarao, Y.R. Mahajan, Ceram. Int. 22 (1996) 353.

[7] M. Lodhe, A. Selvam, A. Udayakumar, M. Balasubramanian, Ceram. Int. 42 (2016) 2393.

[8] N.A.L. Mansour, S.B. Hanna, Brit. Ceram. Trans. J. 78, 6 (1979) 132.

[9] P. Gorthy, M. Pudukottah G., J. Am. Ceram. Soc. 82, 6 (1999) 1393.

[10] M. Ali, M. Ahmad Tindyala, J. Asian Ceram. Soc. 3 (2015) 311.

[11] J. Li, T. Shiray, M. Fuji, Adv. Powder Technol. 24 (2013) 838.

[12] B.V. Radhakrishna Bhat, G.P. Sanghi G., Bull. Mater. Sci. 9, 4 (1987) 295.

[13] A.K. Ray, G. Mahanty, A. Ghose, J. Mater. Sci. Lett. 10 (1991) 227.

[14] G.J. Lee, I.B. Cutler, Am. Ceram. Soc. Bull. 54 (1975) 195.

[15] Y.L. Chiew, K.Y. Cheong, Mater. Sci. Eng. B 176 (2011) 951.

[16] M. Sarangi, B. Mallick, S.C. Mishra, T.N. Tiwari, P. Nayak, J. Phys. D Appl. Phys. 46 (2013) 1.

[17] K. Janghorban, H.R. Tazesh, Ceram. Int. 25 (1999) 7.

[18] S. Somiya, Y. Inomata, Silicon carbide ceramics: 1, fundamental and solid reaction, Elsevier, London (1991) 250.

[19] US Dept. Agricult., "Grain: world markets and trade", https://apps.fas.usda.gov, ac. 22/11/2017.

[20] Comp. Nac. Abastec., "Acompanhamento da safra brasileira: grãos, segundo levantamento, v.4, safra 2017/18" (2017) 125.

[21] R.V. Krishnarao, M.M. Godkhindi, Ceram. Int. 18 
(1992) 243.

[22] R.V. Krishnarao, M.M. Godkhindi, M. Chakraborty, J. Mater. Sci. 27 (1992) 1227.

[23] R.V. Krishnarao, M.M. GodkhindiI, Ceram. Int. 18 (1992) 185.

[24] R.V. Krishnarao, J. Mater. Sci. Lett. 12 (1993) 1268.

[25] R.V. Krishnarao, J. Subrahmanyam, Ceram. Int. 22 (1996) 489.

[26] R.V. Krishnarao, J. Eur. Ceram. Soc. 12 (1993) 395.

[27] R.V. Krishnarao, J. Mater. Sci. 30 (1995) 3645.
[28] E.P. Gorzkowski, S.B. Qadri, B.B. Rath, R. Goswami, J.D. Caldwell, J. Electron. Mater. 42, 5 (2013) 799.

[29] L. Sun, K. Gong, Ind. Eng. Chem. Res. 40 (2001) 5861. [30] C.R.T. Tarley, M.A.Z. Arruda, Chemophere 54 (2014) 987.

[31] R.V. Krishnarao, M.M. Godkhindi, M. Chakraborty, P.G. Mukunda, J. Mater. Sci. 29 (1994) 2741.

[32] S.F. Moustafa, M.B. Morsi, A. Alm El-Din, Can. Metall. Q. 36, 5 (1997) 355.

(Rec. 03/12/2019, Rev. 22/01/2020, 06/03/2020, Ac. 13/03/2020) 